\title{
Application of oxo-manganese complex immobilized on ion-exchange polymeric film as biomimetic sensor for nitrite ions
}

\author{
Wesley B.S. Machini, Marcos F.S. Teixeira* \\ Faculty of Science and Technology, São Paulo State University (UNESP), Roberto Simonsen St, 305, CEP 19060-900 Presidente Prudente, SP, Brazil
}

\section{A R T I C L E I N F O}

\section{Article history:}

Available online 15 January 2015

\section{Keywords:}

Biomimetic oxo-manganese complex

Biomimetic activity

Electrocatalytic nitrite sensor

Electrochemical sensor

Michaelis-Menten

Nitrite oxidase

\begin{abstract}
A B S T R A C T
A biomimetic sensor based on oxo-bridged dinuclear manganese-phenanthroline complex immobilized into an ion-exchange polymeric film deposited on glassy carbon electrode was applied to detection of nitrite ions and studied according to their kinetics parameters. The cyclic voltammetry at the modified electrode in universal buffer showed a two electron oxidation/reduction of the couple $\mathrm{Mn}^{\mathrm{IV}}(\mu-\mathrm{O})_{2} \mathrm{Mn}^{\mathrm{IV}} / \mathrm{Mn}^{\mathrm{III}}(\mu-\mathrm{O})_{2} \mathrm{Mn}^{\mathrm{III}}$ and electrocatalytic property toward nitrite oxidation with a decrease of the overpotential of $320 \mathrm{mV}$ compared with the bare glassy carbon electrode. A plot of the anodic current $v s$. the nitrite ions concentration for potential fixed $(+0.480)$ at the biomimetic sensor was linear in the $2.49 \times 10^{-6}$ to $9.90 \times 10^{-6} \mathrm{~mol} \mathrm{~L}^{-1}$ concentration range with a detection limit of $6.50 \times 10^{-6} \mathrm{~mol} \mathrm{~L}^{-1}$. The kinetic mechanism was derived by Michaelis-Menten, then, kinetics parameters were calculated through four methods: Lineweaver-Burke, Eadie-Hofstee, Hanes-Woolf and Nonlinear curve fitting. The best results were Michaelis-Menten rate constant $=3.42 \mu \mathrm{mol} \mathrm{L}^{-1}$, catalytic rate constant $=0.0114 \mathrm{~s}^{-1}$, catalytic efficiency $=3.3 \times 10^{3}(\mathrm{~mol} \mathrm{~L})^{-1} \mathrm{~s}^{-1}$ and heterogeneous electrochemical rate constant $=1.15 \times 10^{-5} \mathrm{~cm} \mathrm{~s}^{-1}$.
\end{abstract}

(c) 2015 Elsevier B.V. All rights reserved.

\section{Introduction}

Nitrite ions become important and extensively used because of their high reactivity and may act as an oxidizing, reducing or nitrosing agent, beyond the possibility of being converted to a variety of compounds, including nitrous acid, nitrogen oxides and nitrates, and the possibility to be used as a stabilizer and preservative in meats, canned foods, cheeses, among others food [1]. In contrast, there is evidence that ingestion of large amounts of nitrite may be linked to cancer of the stomach [2,3], bowel, leukemia and the appearance of brain tumors in children [4].

Then, due to its potential toxicity, a series of rules that restrict their level in drinking water and food products were implemented, such as, the World Health Organization (WHO/SDE/WSH/07.01/16) stipulates that maximum admissible levels of nitrite ions in drinking water at $3 \mathrm{ppm}$. In Brazil, the National Health Surveillance Agency (ANVISA) establishes for foods the maximum value of $0.015 \mathrm{~g} / 100 \mathrm{~g}$ or $0.015 \mathrm{~g} / 100 \mathrm{~mL}$ of nitrite ions (as sodium nitrite), as a stabilizer in color and conservative. In this way, different methods for detection and quantification of nitrite ions have been

\footnotetext{
* Corresponding author. Tel.: +55 18 32295749; fax: +55 1832215682.

E-mail address: funcao@fct.unesp.br (M.F.S. Teixeira).
}

developed, among them, electrophoresis [5,6], chemiluminescence [7], chromatography [8], colorimetry [9], fluorometry [10], gas chromatography-mass spectrometry [11], polarography [12], spectrophotometry [13-15], stopped-flow [16] and electrochemistry [17-19].

In the development of electrochemical sensors for nitrite ions highlights the use of biosensors and non-enzymatic sensors. For nitrite biosensing there are many reports using enzymes [20], as an amperometric biosensor for nitrite based on cytochrome $c$ immobilized on a gold electrode that was modified with Nafion ${ }^{\circledR}$ and a $\mathrm{Cu}-\mathrm{Mg}-\mathrm{Al}$ layered double hydroxide, which exhibited bioelectrocatalytic activity for the oxidation of nitrite with a linear range from 0.75 to $123 \mu \mathrm{mol} \mathrm{L}^{-1}$, detection limit of $0.20 \mu \mathrm{mol} \mathrm{L}^{-1}$ and Michaelis-Menten constant of $0.08 \mathrm{mmol} \mathrm{L}^{-1}$ [21]. In another way, several electrochemical sensors for nitrite ions based on nonenzymatic molecules have been developed (Table 1). Recently, Azad and Ganesan studied the electrocatalytic oxidation of nitrite ions based on $\mathrm{Fe}(\mathrm{bpy})_{3}{ }^{2+}$ (where bpy $=2,2^{\prime}$-bipyridyl) immobilized on ionexchanged polymer coated glassy carbon electrode with an efficient amperometric response for $\mathrm{NO}_{2}{ }^{-}[22]$. At the $\mathrm{CG} / \mathrm{Nf} / \mathrm{Fe}(\mathrm{bpy})_{3}{ }^{2+}$, the peak current increased linearly up with successive additions of nitrite from 0.2 to $20 \mathrm{mmol} \mathrm{L}^{-1}$, reaching a detection limit of $0.03 \mathrm{mmol} \mathrm{L}^{-1}$ and standard deviations less than $2.0 \%$ to six measurements of reproducibility. 
Table 1

A brief review of nonenzymatic sensors for nitrite ions.

\begin{tabular}{lc}
\hline Material & Ref. \\
\hline Au nanoparticles/poly(3-methylthiophene) & {$[57]$} \\
Poly(1,3-diaminobenzene) & {$[58]$} \\
Poly(Nile-Blue) & {$[59]$} \\
Thionine/aligned carbon nanotubes & {$[60]$} \\
Au-Fe(III) nanoparticle & {$[44]$} \\
Chemically reduced grapheme oxide & {$[61]$} \\
Poly(amidoamine)/carbon nanotubes & {$[62]$} \\
Poly(vanillin)/carbon nanotube & {$[63]$} \\
Oxovanadium(IV)-4-methyl salophen & {$[64]$} \\
Poly(diphenylamine)/Pt nanoparticles & {$[65]$} \\
Chitosan-carboxylated/multiwall carbon nanotube & {$[66]$} \\
Poly(ethylenimine)/graphene oxide/Au nanoparticles & {$[67]$} \\
Poly(vinylimidazole) & {$[68]$} \\
Tris(1,10-phenanthroline)iron(II)-bentonite & {$[69]$} \\
Fe $\mathrm{O}_{3}$ nanoparticles/reduced graphene oxide nanosheets & {$[70]$} \\
Titanium dioxide nanoparticles/ionic liquid & {$[71]$} \\
\hline
\end{tabular}

A novel advance in the construction of electrochemical sensors is the development and application of biomimetic elements [23],which imitate natural reactions and enzymatic processes, aiming to improve the chemical properties itself [24], beyond stability when compared to biosensors. A biomimetic sensor can be characterized as a device consisting of a recognition element closely linked to a transducer that has equal or greater sensitivity and stability as sensors which use biological components, such as antibodies and enzymes. Among these biomimetic molecules, several metallic complexes have been studied by mimic enzyme active sites, such as the polynuclear complexes of manganese with $\mu$-oxo units, which are related to the oxygen-evolving complex (OEC) in photosystem II (PSII), by presenting electron-transfer process of multi-stage that result in good stability for high oxidation states and the ability to charge exchange between metal ions [25-27].

In this manuscript we studied application of the oxobridged dinuclear manganese-phenanthroline complex $\left(\left[\mathrm{Mn}_{2}{ }^{\mathrm{IV}} \mathrm{O}_{2}\right.\right.$ (phen $\left.)_{2}\left(\mathrm{H}_{2} \mathrm{O}\right)_{2}\right]^{4+}$ ) incorporated into a Nafion ${ }^{\circledR}$ film coated on the glassy carbon electrode as biomimetic sensor in the oxidation of nitrite ions and determined their kinetics parameters according to the Michaelis-Menten model.

\section{Experimental}

\subsection{Reagents and solutions}

All the chemicals were of analytical high-purity. A universal buffer solution (citric acid, monopotassium phosphate, boric acid and diethyl barbituric acid [28]) containing $\mathrm{NaCl} 0.5 \mathrm{~mol} \mathrm{~L}^{-1}$ $(\mathrm{pH}=5.00)$ was used as a supporting electrolyte, where the adjustment was made by adding $\mathrm{HCl}$ and/or $\mathrm{NaOH}$ concentrated. The analyte was prepared by the addition of sodium nitrite $\left(1.0 \mathrm{mmol} \mathrm{L}^{-1}\right)$ to the solution of supporting electrolyte. The Nafion ${ }^{\circledR}$ solutions (tetrafluoroethylene-perfluoro-3,6-dioxa-4methyl-7-octenesulfonic acid copolymer) used for the formation of ion-exchange polymeric film on the electrode surface, were prepared from the concentrated solution of the perfluorosulfonate polymer $5 \%(\mathrm{v} / \mathrm{v})$ diluted in absolute ethanol.

\subsection{Synthesis of biomimetic complex}

The immobilization of the oxo-bridged dinuclear manganese-phenanthroline complex on Nafion ${ }^{\circledR}$ thin film was performed starting from the $\left.\left[\mathrm{Mn}^{\mathrm{IV}}{ }_{3} \mathrm{O}_{4} \text { (phen }\right)_{4}\left(\mathrm{H}_{2} \mathrm{O}\right)_{2}\right]^{4+}$ complex. The synthesis of $\left.\left[\mathrm{Mn}_{3} \mathrm{O}_{4} \text { (phen }\right)_{4}\left(\mathrm{H}_{2} \mathrm{O}\right)_{2}\right]\left(\mathrm{NO}_{3}\right)_{4}$ complex was performed according to procedure found in the literature [29]. It was added $10.16 \mathrm{mmol}$ of the ligand phenanthroline to a solution of $4.94 \mathrm{mmol}$ of $\mathrm{Mn}(\mathrm{OAc})_{2} \cdot \mathrm{H}_{2} \mathrm{O}$ in dilute nitric acid $\left(1.6 \mathrm{~mol} \mathrm{~L}^{-1}\right.$, $20 \mathrm{~mL}$ ) and aqueous solution of $\left(\mathrm{NH}_{4}\right)_{2} \mathrm{Ce}\left(\mathrm{NO}_{3}\right)_{6}(6.02 \mathrm{mmol})$, obtain a brown solution, which was filtered and kept at room temperature. The precipitate formed was filtered, washed with dilute nitric acid $\left(0.2 \mathrm{~mol} \mathrm{~L}^{-1}\right)$ and dried at room temperature. The electronic absorption spectrum of complex in aqueous solution showed two maxima peaks in $623 \mathrm{~nm}$ and $784 \mathrm{~nm}$ (Supplementary material). The complex also characterized by cyclic voltammetry in aqueous solution showed three redox couples and an irreversible cathodic process (Supplementary material).

\subsection{Construction of $\left.\left[\mathrm{Mn}_{2}{ }^{I V} \mathrm{O}_{2} \text { (phen }\right)_{2}\left(\mathrm{H}_{2} \mathrm{O}\right)_{2}\right]^{4+} / \mathrm{Nafion}^{\circledR} / \mathrm{GC}$ modified electrode}

The $\left.\left[\mathrm{Mn}_{2}{ }^{\mathrm{IV}} \mathrm{O}_{2} \text { (phen }\right)_{2}\left(\mathrm{H}_{2} \mathrm{O}\right)_{2}\right]^{4+} / \mathrm{Nafion}^{\circledR} / \mathrm{GC}$ modified electrode was constructed by depositing a rate of $5.0 \mu \mathrm{L}$ of solution of Nafion ${ }^{\circledR}$ $5 \%(v / v)$ on the electrode surface by the casting method. Next, it was left on desiccators for $4 \mathrm{~h}$ to complete solvent evaporation. Thereafter, successive drops of $\left.1.0 \mathrm{mmol} \mathrm{L}^{-1}\left[\mathrm{Mn}_{3} \mathrm{O}_{4} \text { (phen }\right)_{4}\left(\mathrm{H}_{2} \mathrm{O}\right)_{2}\right]^{4+}$ complex in $\mathrm{NaNO}_{3} 0.5 \mathrm{~mol} \mathrm{~L}^{-1}$ were added to the electrode surface coated with the polymeric membrane, for $4 \mathrm{~h}$ for immobilization of electroactive material, and finally, the modified electrode was washed with deionized water, dried at room temperature and submitted to electrochemical measurements.

\subsection{Performance electrochemical}

The cyclic voltammetry measurements were made using a potentiostat/galvanostat microAutolab Type III (Eco Chimie) connected to a microcomputer, in a thermostated electrochemical cell with three electrodes, being the platinum wire (Pt) as auxiliary electrode, saturated calomel electrode (SCE) as reference electrode and modified glassy carbon electrode $\left(\left[\mathrm{Mn}_{2}{ }^{\mathrm{IV}} \mathrm{O}_{2} \text { (phen }\right)_{2}\left(\mathrm{H}_{2} \mathrm{O}\right)_{2}\right]^{4+} / \mathrm{Nafion}^{\circledR} / \mathrm{GC}$ ) as working electrode (area $=0.06 \mathrm{~cm}^{2}$ ). Before use, the working electrode was subjected to a polishing with alumina solution $\left(0.5 \mathrm{mmol} \mathrm{L}^{-1}\right)$ and then with ethanol. All the electrochemical measurements were realized in the absence of dissolved oxygen.

\subsection{Performance of the modified electrode as biomimetic sensor for nitrite ions}

The nitrite ions determination was made by application of potential via linear voltammetry using a potential range from -0.9 to $0.9 \mathrm{~V} v s$. SCE at a scan rate of $25 \mathrm{mV} \mathrm{s}^{-1}$. The $\left.\left[\mathrm{Mn}_{2}{ }^{\mathrm{IV}} \mathrm{O}_{2} \text { (phen }\right)_{2}\left(\mathrm{H}_{2} \mathrm{O}\right)_{2}\right]^{4+} / \mathrm{Nafion}{ }^{\circledR} / \mathrm{GC}$ was submitted to potential scans in $20 \mathrm{~mL}$ of universal buffer with $0.5 \mathrm{~mol} \mathrm{~L}^{-1} \mathrm{NaCl}$ at pH 5.0 (deoxygenated with high purity nitrogen). The evaluation of the electrochemical performance of sensor for nitrite ions was conducted by the addition of the analyte $\left(1.0 \mathrm{mmol} \mathrm{L}^{-1}\right)$ in the electrochemical cell. All the electrochemical measurements of nitrite detection were realized in the absence of dissolved oxygen, because its presence may limit the determination of $\mathrm{NO}_{2}{ }^{-}[30,31]$.

\section{Results and discussion}

3.1. Basic characteristics of $\left.\left[\mathrm{Mn}_{2}{ }^{I V} \mathrm{O}_{2} \text { (phen }\right)_{2}\left(\mathrm{H}_{2} \mathrm{O}\right)_{2}\right]^{4+} / \mathrm{Nafion}^{\circledR} /$ GC modified electrode

The electrochemical behavior of the oxo-bridged binuclear manganese-phenanthroline complex incorporated into tetrafluoroethylene-perfluoro-3,6-dioxa-4-methyl-7-octenesulfonic acid thin film coated on a glassy carbon electrode was studied by cyclic voltammetry in universal buffer $(\mathrm{pH}=5.0)$ containing $\mathrm{NaCl} 0.5 \mathrm{~mol} \mathrm{~L}^{-1}$. Cyclic voltammogram obtained for the modified 


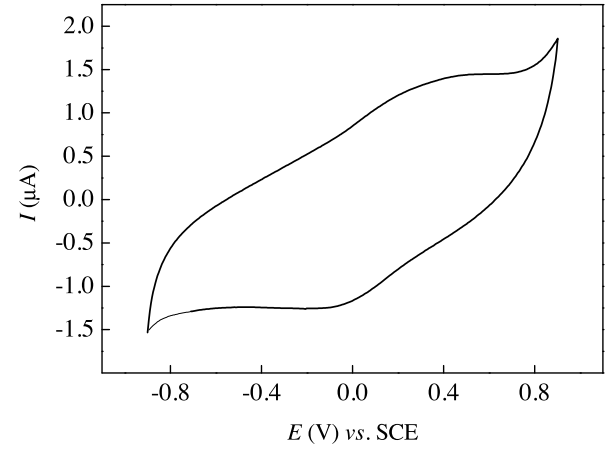

Fig. 1. Cyclic voltammogram for $\left.\left[\mathrm{Mn}_{2}{ }^{\mathrm{IV}} \mathrm{O}_{2} \text { (phen }\right)_{2}\left(\mathrm{H}_{2} \mathrm{O}\right)_{2}\right]^{4+} / \mathrm{Nafion}{ }^{\circledR} / \mathrm{GC}$ electrode in universal buffer containing $\mathrm{NaCl} 0.5 \mathrm{~mol} \mathrm{~L}^{-1}$ solution $(\mathrm{pH}=5.0)$ from -0.9 to $0.9 \mathrm{~V}$ $v s$. SCE potential range at $25 \mathrm{mV} \mathrm{s}^{-1}$.

electrode (Fig. 1) revealed aquasi-reversible system with only one redox couple $\left(E_{\mathrm{pa}}=0.48 \mathrm{~V}\right.$ and $E_{\mathrm{pc}}=-0.15 \mathrm{~V} v \mathrm{~s}$. SCE) which is attributed to redox process of $\mathrm{Mn}^{\mathrm{IV}} / \mathrm{Mn}^{\mathrm{III}}$, peak-to-peak separation $\left(\Delta E_{p}\right)$ of $0.630 \mathrm{~V} v s$. SCE and half potential $\left(E_{p / 2}\right)$ of $0.165 \mathrm{~V} v s$. SCE.

The complex immobilization on the polymeric membrane of tetrafluoroethylene-perfluoro-3,6-dioxa-4-methyl-7-octenesulfonic acid causes a change on the molecular structure and the number of metallic centers of the complex. This change has been widely discussed by the authors previously [32]. In this way, the electrochemical behavior observed is assigned only to the material $\left.\left[\mathrm{Mn}_{2}{ }^{\mathrm{IV}} \mathrm{O}_{2} \text { (phen }\right)_{2}\left(\mathrm{H}_{2} \mathrm{O}\right)_{2}\right]^{4+}$ on the surface of the glassy carbon electrode, according to Scheme 1:

$$
\begin{aligned}
& {\left[\mathrm{Mn}_{2}{ }^{\mathrm{IV}}(\mu-\mathrm{O})_{2}(\text { phen })_{2}\left(\mathrm{H}_{2} \mathrm{O}\right)_{2}\right]^{4+}+\mathrm{H}^{+}+2 \mathrm{e}^{-}} \\
& \rightleftharpoons\left[\mathrm{Mn}_{2}{ }^{\mathrm{III}}(\mu-\mathrm{O})(\mu-\mathrm{OH})(\text { phen })_{2}\left(\mathrm{H}_{2} \mathrm{O}\right)_{2}\right]^{3+}
\end{aligned}
$$

The effect of the potential scans rates (5 to $200 \mathrm{mV} \mathrm{s}^{-1}$ ) on the voltammetric response for the modified electrode in universal buffer ( $\mathrm{pH}$ 5.0) solution $0.1 \mathrm{~mol} \mathrm{~L}^{-1}$ containing $\mathrm{NaCl} 0.5 \mathrm{~mol} \mathrm{~L}^{-1}$ was investigated. The recorded cyclic voltammograms exhibit an increase of anodic peak current as the scan rate increases and a linearity between the anodic peak current with the square root of scan rates, suggesting that the redox process follows a diffusioncontrolled mechanism (Supplementary material). This behavior indicates which the mobility of counter ions of the supporting electrolyte is required to maintain the electroneutrality of the electrode surface during the redox processes $[33,34]$. Thus, the surface concentration of electroactive species was estimated by background-corrected electric charge $(Q)$ obtained in the anodic peaks process according with the theoretical relationship [35]:

$\Gamma=\frac{Q}{n F A}$

where $\Gamma$ is the concentration of electroactive species $\left(\mathrm{mol} \mathrm{cm}^{-2}\right)$, the number of electrons transferred (assuming $\approx 2$ ), $F$ the Faraday constant $\left(96,485 \mathrm{C} / \mathrm{mol} \mathrm{e}^{-}\right)$and $A$ is the electrode area $\left(0.06 \mathrm{~cm}^{2}\right)$. The $\Gamma$ value was calculated for $5 \mathrm{mV} \mathrm{s} \mathrm{s}^{-1}$ under the surface adsorption-controlled electrochemical process [36-41] and the concentration of electroactive species was found to be $3.45 \mathrm{nmol} \mathrm{cm}^{-2}$.

\subsection{Application of $\left.\left[\mathrm{Mn}_{2}{ }^{I V} \mathrm{O}_{2} \text { (phen }\right)_{2}\left(\mathrm{H}_{2} \mathrm{O}\right)_{2}\right]^{4+} / \mathrm{Nafion}^{\circledR} / \mathrm{GC}$ as biomimetic sensor for nitrite ions}

The determination of nitrite ions in conventional electrodesis generally difficult, because they occur at high values of potential [42]. Recently, Kozub and collaborators reported the oxidation of nitrite ions in aqueous solution using a bare glassy carbon electrode

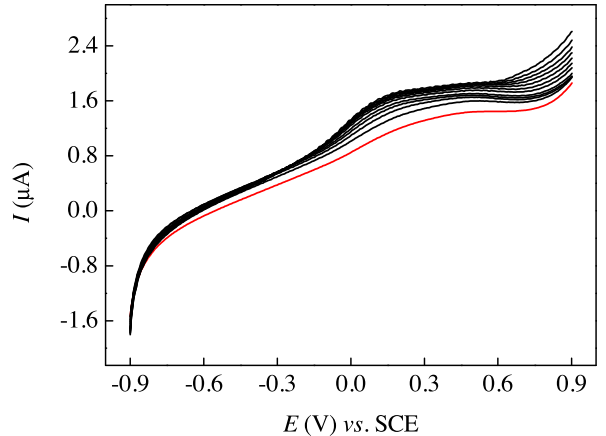

Fig. 2. Linear voltammograms for $\left.\left[\mathrm{Mn}_{2}{ }^{\mathrm{IV}} \mathrm{O}_{2} \text { (phen }\right)_{2}\left(\mathrm{H}_{2} \mathrm{O}\right)_{2}\right]^{4+} / \mathrm{Nafion}{ }^{\circledR} / \mathrm{GC}$ electrode in universal buffer containing $\mathrm{NaCl} 0.5 \mathrm{~mol} \mathrm{~L}^{-1}$ solution $(\mathrm{pH}=5.0)$ in absence (red line) and in presence of $2.49 \times 10^{-6} ; 3.98 \times 10^{-6} ; 5.47 \times 10^{-6} ; 7.44 \times 10^{-6}$; $9.90 \times 10^{-6} ; 1.48 \times 10^{-5} ; 2.44 \times 10^{-5} ; 3.85 \times 10^{-5} ; 5.21 \times 10^{-5} ; 6.98 \times 10^{-5} \mathrm{~mol} \mathrm{~L}^{-1}$ of nitrite ions (black lines). (For interpretation of the references to color in this figure legend, the reader is referred to the web version of this article.)

by three different techniques [43]. Using cyclic voltammetry, the anodic peak for nitrite oxidation increased at $+0.8 \mathrm{~V} v \mathrm{~s}$. SCE in linear range from $5.0 \times 10^{-5}$ to $4.7 \times 10^{-4} \mathrm{~mol} \mathrm{~L}^{-1}$ with a limit of detection $0.2 \mathrm{mmol} \mathrm{L}^{-1}$ and sensitivity of $3.3 \times 10^{-2} \mathrm{AL} \mathrm{mol}^{-1}$. On the other hand, analyzing modified electrodes, a significant decrease in the values of the electrooxidation potential can be obtained, such as the $\mathrm{Au}-\mathrm{Fe}(\mathrm{III})$ nanoparticle modified glassy carbon electrode developed by Liu et al. [44], which demonstrated the electrocatalytic oxidation of nitrite at $+0.73 \mathrm{~V} v$ s. SCE (decrease of the overpotential of $130 \mathrm{mV}$ compared to their unmodified electrode) with concentration range of $3.0 \times 10^{-7}$ to $1.5 \times 10^{-4} \mathrm{~mol} \mathrm{~L}^{-1}$ and detection limit of $2.0 \times 10^{-7} \mathrm{~mol} \mathrm{~L}^{-1}$ in weak acid solution.

In the present paper, the cyclic voltammograms were obtained in the absence and in the presence of nitrite in universal buffer containing $\mathrm{NaCl} 0.5 \mathrm{~mol} \mathrm{~L}^{-1}(\mathrm{pH}=5.0)$, as showed in Fig. 2. The anodic peak current of the $\left.\left[\mathrm{Mn}_{2}{ }^{\mathrm{IV}} \mathrm{O}_{2} \text { (phen }\right)_{2}\left(\mathrm{H}_{2} \mathrm{O}\right)_{2}\right]^{4+} / \mathrm{Nafion}{ }^{\circledR} / \mathrm{GC}$ electrode increase significantly with the addition of nitrite ions in solution, as well as a decrease in the overpotential of $320 \mathrm{mV}$ compared with unmodified glassy carbon electrode [43].

The results obtained for the modified electrode show its electrocatalytic activity for oxidation of nitrite and its biomimetic properties. The mechanism of nitrite ions electrooxidation has been reported by Guidelli et al. [45]. According to this mechanism proposed, the nitrite ions are electrooxidized to nitrogen dioxide, followed by a disproportionation into nitrite and nitrate, thus regenerating the depolarizer, which constitutes the rate-determining step of the overall electrode process, as represented:

$$
\begin{aligned}
& 2\left(\mathrm{NO}_{2}^{-} \rightleftharpoons \mathbf{N O}_{2}+\mathbf{e}^{-}\right) \\
& \mathbf{2 N O}_{\mathbf{2}}+\mathbf{H}_{2} \mathbf{O} \rightarrow \mathbf{N O}_{3}^{-}+\mathrm{NO}_{2}^{-}+2 \mathrm{H}^{+} \\
& \mathrm{NO}_{2}^{-}+\mathbf{H}_{2} \mathbf{O} \rightarrow \mathbf{N O}_{3}^{-}+2 \mathrm{H}^{+}+2 \mathrm{e}^{-}
\end{aligned}
$$

In this way, the oxidation mechanism at $\left.\left[\mathrm{Mn}_{2}{ }^{\mathrm{IV}} \mathrm{O}_{2} \text { (phen }\right)_{2}\left(\mathrm{H}_{2} \mathrm{O}\right)_{2}\right]^{4+} / \mathrm{Nafion}^{\circledR} / \mathrm{GC}$ occurs through the diffusion of the $\mathrm{NO}_{2}{ }^{-}$ions to the electrode surface and reduces the $\mathrm{Mn}^{\mathrm{IV}}$ complex immobilized on the surface of glassy carbon (chemical step, Eq. (6)), followed by one electrooxidation process (electrochemical step, Eq. (7)):

$$
\begin{aligned}
& \mathrm{Mn}^{\mathrm{IV}}(\mu-\mathrm{O})_{2} \mathrm{Mn}^{\mathrm{IV}}{ }_{(\text {sup })}+\mathrm{NO}_{2}{ }^{-}{ }_{(\text {aq })}+\mathrm{H}_{2} \mathrm{O} \\
& \rightarrow \mathrm{Mn}^{\mathrm{III}}(\mu-\mathrm{O})(\mu-\mathrm{OH}) \mathrm{Mn}^{\mathrm{III}}{ }_{(\text {sup })}+\mathrm{NO}_{3}{ }^{-}{ }_{(\mathrm{aq})}+\mathrm{H}^{+}
\end{aligned}
$$

$$
\begin{aligned}
& \mathrm{Mn}^{\mathrm{III}}(\mu-\mathrm{O})(\mu-\mathrm{OH}) \mathrm{Mn}^{\mathrm{III}}(\text { sup }) \\
& \quad \rightarrow \mathrm{Mn}^{\mathrm{IV}}(\mu-\mathrm{O})_{2} \mathrm{Mn}_{(\text {sup })}^{\mathrm{IV}}+\mathrm{H}^{+}+2 \mathrm{e}^{-}
\end{aligned}
$$




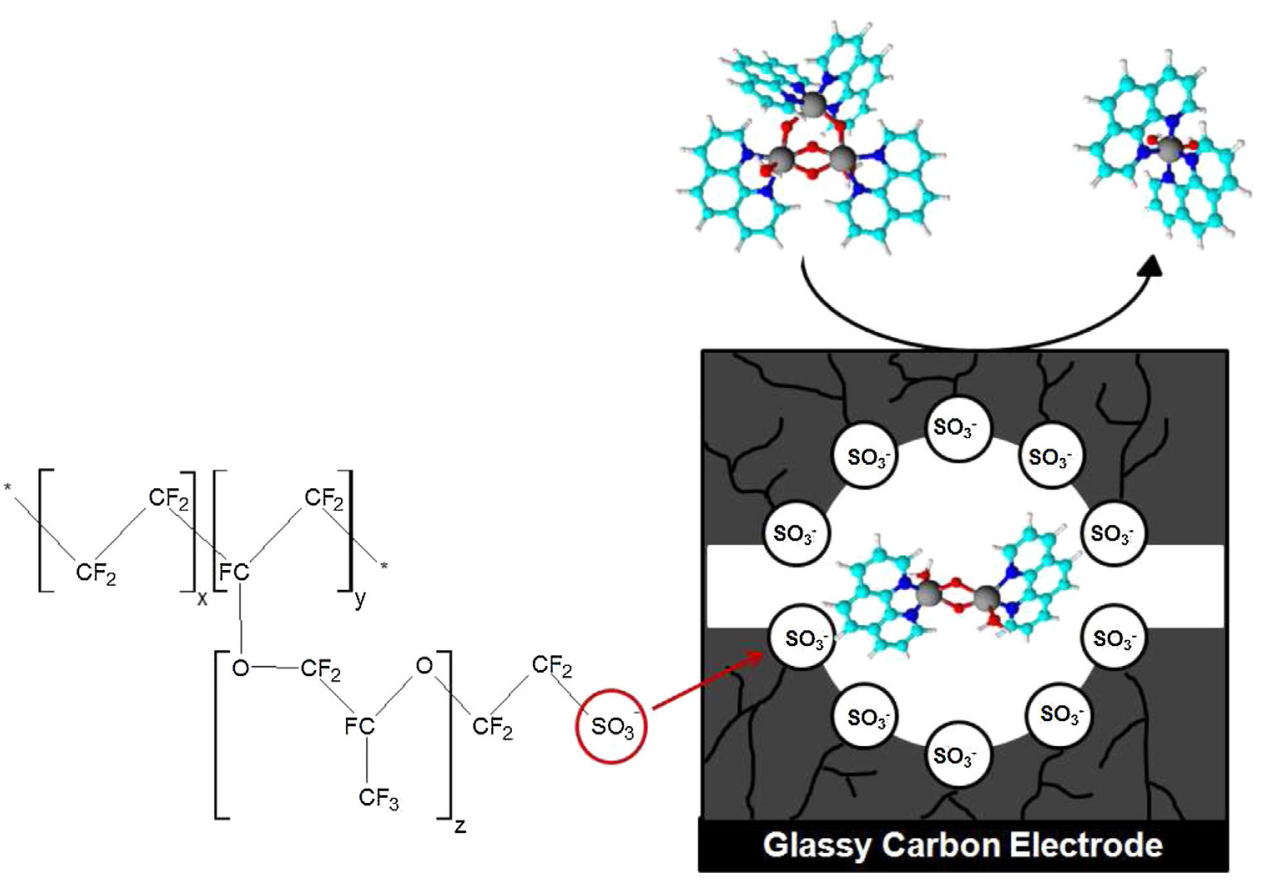

Scheme 1. Formation of the oxo-bridged dinuclear manganese-phenanthroline complex on Nafion ${ }^{\circledR}$ polymeric membrane.

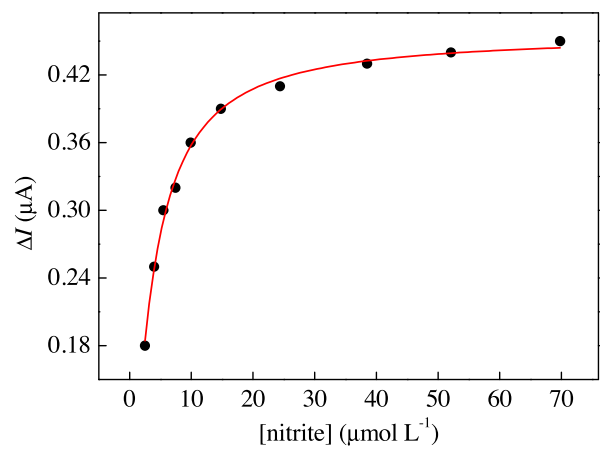

Fig. 3. Relationship between the current response of the biomimetic sensor with the nitrite ions concentration. Working potential $=0.480 \mathrm{~V} v s$. SCE.

Successive additions of $\mathrm{NO}_{2}{ }^{-}$ions were made to evaluate the performance of the modified electrode as a sensor. The values of anodic peak current vary linearly in a concentration range from $2.49 \times 10^{-6} \mathrm{~mol} \mathrm{~L}^{-1}$ to $9.09 \times 10^{-6} \mathrm{~mol} \mathrm{~L}^{-1}$ with a detection limit of $6.50 \times 10^{-6} \mathrm{~mol} \mathrm{~L}^{-1}$ and sensibility of $0.0228 \mu \mathrm{A} \mathrm{L} \mathrm{mol}^{-1}$ (Fig. 3). At concentrations greater than $1.00 \times 10^{-5} \mathrm{~mol} \mathrm{~L}^{-1}$, a saturation of the electrocatalytic sites was observed. This phenomenon can be explained by the adsorption of nitrite ions and subsequent saturation of the electroactive sites of $\mathrm{Mn}^{\mathrm{IV}}$ on the electrode surface.

The detection performances of the $\left[\mathrm{Mn}_{2}{ }^{\mathrm{IV}} \mathrm{O}_{2}(\text { phen })_{2}\left(\mathrm{H}_{2} \mathrm{O}\right)_{2}\right]^{4+}$ / Nafion ${ }^{\circledR} / G C$ sensor in the oxidation of nitrite ions were compared with biosensors and non-enzymatic sensors in the literature (Table 2). It's important to emphasize that most work related to detection of nitrite ions by electrochemical (bio)sensors are based on its reduction [20], unlike the mechanism presented here. According to Table 2, it can be seen that the glassy carbon electrode coated with Nafion ${ }^{\circledR}$ film incorporated with the oxomanganese-phenanthroline complex showed a detection limit lower than previously reported studies, proving to be a good device for the detection of nitrite ions and a potential sensor for monitoring of the concentration of nitrite ions in real samples.
The biomimetic property of the $\left.\left[\mathrm{Mn}_{2}{ }^{\mathrm{IV}} \mathrm{O}_{2} \text { (phen }\right)_{2}\left(\mathrm{H}_{2} \mathrm{O}\right)_{2}\right]^{4+}$ / Nafion ${ }^{\circledR} / G C$ electrode can be observed through of the profile of anodic current vs. $\mathrm{NO}_{2}{ }^{-}$concentration, which exhibit similar characteristic to the Michaelis-Menten model of an enzymatic electrode. Therefore, the Michaelis-Menten equation applied to $\mathrm{NO}_{2}{ }^{-}$ for the steady-state of catalytic current $i_{\text {SSC }}$ can be expressed as [46-48]:

$i_{\mathrm{SSC}}=\frac{n F A \Gamma k_{\mathrm{cat}}\left[\mathrm{NO}_{2}^{-}\right]}{K_{\mathrm{M}}^{\mathrm{app}}+\left[\mathrm{NO}_{2}^{-}\right]}=\frac{i_{\max }\left[\mathrm{NO}_{2}^{-}\right]}{K_{\mathrm{M}}^{\mathrm{app}}+\left[\mathrm{NO}_{2}^{-}\right]}$

where $n$ is the number of electrons involved in the catalytic reaction, $K_{\mathrm{M}}{ }^{\text {app }}$ is the apparent Michaelis-Menten constant, A $\left(\mathrm{cm}^{2}\right)$ is the electrode area, $\Gamma\left(\mathrm{mol} \mathrm{cm}{ }^{-2}\right)$ is the electroactive concentration on the electrode surface, $k_{\mathrm{cat}}$ is the catalytic rate constant, $i_{\text {max }}$ is the maximum catalytic current $\left(i_{\max }=n F A \Gamma k_{\mathrm{cat}}\right)$ and $\left[\mathrm{NO}_{2}{ }^{-}\right]$ is the concentration of nitrite ions. Thus, the kinetic parameters were obtained from four ways through of rearrangement of the Michaelis-Menten equation:

By Lineweaver-Burke (LB) expression:

$$
\begin{aligned}
\frac{1}{i_{\mathrm{pa}}} & =\frac{K_{\mathrm{M}}^{\mathrm{app}}}{n F A \Gamma k_{\mathrm{cat}}\left[\mathrm{NO}_{2}^{-}\right]}+\frac{1}{n F A \Gamma k_{\mathrm{cat}}}=\frac{S_{\mathrm{LB}}}{\mathrm{NO}_{2}^{-}}+I_{\mathrm{LB}} \\
I_{\mathrm{LB}} & =\frac{1}{n F A \Gamma k_{\mathrm{cat}}} \\
S_{\mathrm{LB}} & =\frac{K_{\mathrm{M}}^{\mathrm{app}}}{n F A \Gamma k_{\mathrm{cat}}}
\end{aligned}
$$

According to Eadie-Hofstee (EH):

$\frac{i_{\mathrm{pa}}}{\left[\mathrm{NO}_{2}^{-}\right]}=\frac{n F A \Gamma k_{\mathrm{cat}}}{K_{\mathrm{M}}^{\mathrm{app}}}-\frac{i_{\mathrm{pa}}}{K_{\mathrm{M}}^{\mathrm{app}}}=I_{\mathrm{EH}}+S_{\mathrm{EH}} i_{\mathrm{pa}}$

$S_{\mathrm{EH}}=-\frac{1}{K_{\mathrm{M}}^{\mathrm{app}}}$

$I_{\mathrm{EH}}=\frac{n F A \Gamma k_{\mathrm{cat}}}{K_{\mathrm{M}}^{\mathrm{app}}}$ 
Table 2

Analytical features of different sensors for nitrite determination.

\begin{tabular}{|c|c|c|c|}
\hline Material & $E_{\mathrm{pa}}$ & L.D. & Ref. \\
\hline $\mathrm{Ni}$ (II)TSPc film/GCE & $0.94 \mathrm{~V}$ vs. $\mathrm{Ag} / \mathrm{AgCl}$ & $0.149 \mathrm{mM}$ & [72] \\
\hline ND & $1.05 \mathrm{~V} v s . \mathrm{SCE}$ & $0.120 \mathrm{mM}$ & [73] \\
\hline $\mathrm{Fe}(\mathrm{bpy})_{3}{ }^{2+} / \mathrm{Nafion}{ }^{\circledR} / \mathrm{GCE}$ & $1.19 \mathrm{~V} v s . \mathrm{Ag} / \mathrm{AgCl}$ & $0.030 \mathrm{mM}$ & [22] \\
\hline rGO-MWNTs/GCE & $0.80 \mathrm{~V} v s . \mathrm{SCE}$ & $25.0 \mu \mathrm{mol} \mathrm{L}^{-1}$ & {$[74]$} \\
\hline$\left[\mathrm{Mn}_{2}{ }^{\mathrm{IV}} \mathrm{O}_{2}(\text { phen })_{2}\left(\mathrm{H}_{2} \mathrm{O}\right)_{2}\right]^{4+} / \mathrm{Nafion}^{\circledR} / \mathrm{GCE}$ & $0.48 \mathrm{~V} v s . \mathrm{SCE}$ & $6.50 \mu \mathrm{mol} \mathrm{L}^{-1}$ & This work \\
\hline
\end{tabular}

$E_{\mathrm{pa}}=$ Oxidation potential peak of $\mathrm{NO}_{2}{ }^{-}$; L.D. = limit of detection.

Also by Hanes-Woolf (HW):

$\frac{\left[\mathrm{NO}_{2}^{-}\right]}{i_{\mathrm{pa}}}=\frac{\left[\mathrm{NO}_{2}^{-}\right]}{n F A \Gamma k_{\mathrm{cat}}}+\frac{K_{\mathrm{M}}^{\mathrm{app}}}{n F A \Gamma k_{\mathrm{cat}}}=S_{\mathrm{HW}}+\left[\mathrm{NO}_{2}^{-}\right]+l_{\mathrm{HW}}$

$S_{\mathrm{HW}}=\frac{1}{n F A \Gamma k_{\mathrm{cat}}}$

$l_{\mathrm{HW}}=\frac{K_{\mathrm{M}}^{\mathrm{app}}}{n F A \Gamma k_{\mathrm{cat}}}$

and finally, through the curve fitting analysis using nonlinear least square regression program based on the Marquardt-Levenberg algorithm [49]. The incognita $S$ and $I$ denote the slope and intercept of the linearized equations, respectively. Still evaluating the kinetics parameters, the value of the specificity constant (which here we call of $k_{s}$ ) [50] and heterogeneous constant $\left(k_{e}^{\prime}\right)$ were calculated by Eqs. (15) and (16), respectively, for each method.

$k_{s}=\frac{k_{\mathrm{cat}}}{K_{\mathrm{M}}^{\mathrm{app}}}$

$k_{e}^{\prime}=\frac{k_{\mathrm{cat}} \Gamma}{K_{\mathrm{M}}^{\mathrm{app}}}$

The $I_{\mathrm{pa}}{ }^{-1} v$ s. $\left[\mathrm{NO}_{2}{ }^{-}\right]^{-1}$ for Lineweaver-Burke, $I_{\mathrm{pa}} /\left[\mathrm{NO}_{2}{ }^{-}\right] v s . I_{\mathrm{pa}}$ for Eadie-Hofstee and $\left[\mathrm{NO}_{2}{ }^{-}\right] / I_{\mathrm{pa}} v s$. [ $\left.\mathrm{NO}_{2}{ }^{-}\right]$for Hanes-Woolf plots are presented in Fig. 4 and the kinetic results obtained are listed in Table 3.

As can be seen, the Michaelis-Menten kinetic parameters that calculated from four different methods are all in the same order. The Michaelis-Menten constant is related with the affinity of the enzyme (for biosensors) or of the biomimetic complex (as it is our case) for substrate, as well as its concentration required for effective catalysis occurs. Analyzing this parameter, the results reveal a slight difference $(\Delta=0.66)$ between the methods used and low values of Michaelis-Menten constant (order of $\mu \mathrm{mol} \mathrm{L}^{-1}$ ), which indicate that the $\left.\left[\mathrm{Mn}_{2}{ }^{\mathrm{IV}} \mathrm{O}_{2} \text { (phen }\right)_{2}\left(\mathrm{H}_{2} \mathrm{O}\right)_{2}\right]^{4+}$ complex immobilized on a Nafion ${ }^{\circledR}$ polymeric film had a high affinity to $\mathrm{NO}_{2}{ }^{-}$ions. Inclusive, the biomimetic sensor showed better affinity and $K_{M}$ than the nitrite oxidase enzyme from Nitrobacteragilis [51], as also the biosensor which uses cytochrome $c$ as a biological material [21]. The catalytic constant gives a direct measure of the catalytic production of product under optimum conditions (for saturated enzyme). Examining the $\left.\left[\mathrm{Mn}_{2}{ }^{\mathrm{IV}} \mathrm{O}_{2} \text { (phen }\right)_{2}\left(\mathrm{H}_{2} \mathrm{O}\right)_{2}\right]^{4+} / \mathrm{Nafion}^{\circledR} / \mathrm{GC}$, the $k_{\text {cat }}$ can be thought of as the time required by a biomimetic complex to turn over one substrate molecule. In this way, the $k_{\text {cat }}$ values obtained showed a great catalytic production in extremely fast times. The ratio $k_{\text {cat }} / K_{\mathrm{M}}^{\mathrm{app}}$ could be used to analyze the relative rates of reaction of the substrate, when it is catalytically transformed by a material electroactive. This is because, if $K_{\mathrm{M}}^{\mathrm{app}}$ is used on its own as the indicator of specificity, the effect of the substrate will be strongly manifested mainly at values of $[S] / K_{M} \ll 1$. As $[S] / K_{\mathrm{M}}^{\text {app }}$ increases above this value, $k_{\text {cat }}$ becomes the parameter that best describes the better catalytic efficiency of substrate [52]. In this manner, this dichotomy is resolved by using $k_{\text {cat }} / K_{\mathrm{M}}^{\mathrm{app}}$ as specificity constant. Finally, the results indicate that the electrocatalytic mechanism for the biomimetic sensor is dependent on the concentration of
$\mathrm{NO}_{2}{ }^{-}$ions adsorbed on the electrode surface, enabling the calculation of heterogeneous constant, which are comparable to a system with an electron mediation mechanism [53-55].

Another parameter investigated was the reaction order for the oxidation of nitrite ions. Through the logarithm of the anodic current $v s$. the logarithm of the nitrite concentration (Supplementary material) at a constant potential there was obtained a slope of 0.5 . The reaction order of 0.5 is a reaction with the rate-determining step occurs twice [56]. This implies that an intermediate species should be formed twice in one or two
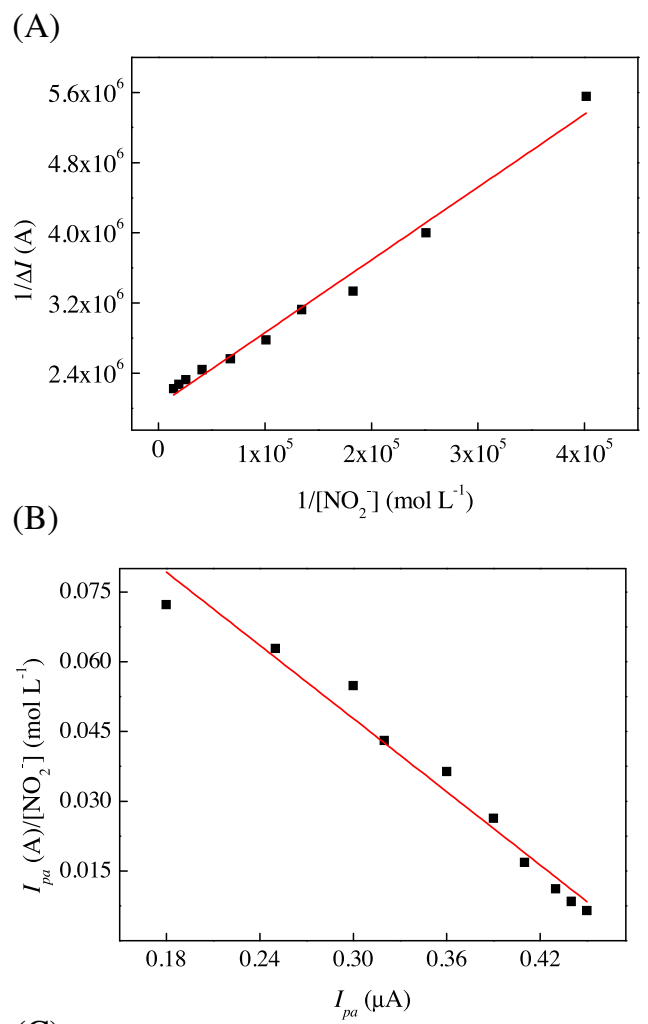

(C)

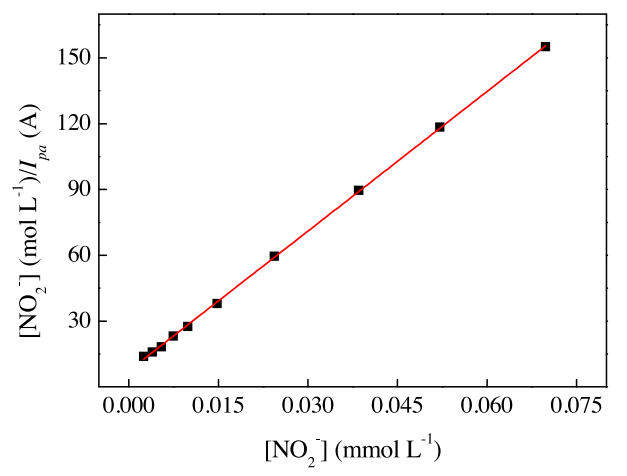

Fig. 4. Michaelis-Menten analysis in terms of Lineweaver-Burke (A), Eadie-Hofstee (B) and Hanes-Woolf (C) plots based on the data of Fig. 3. 
Table 3

Kinetics parameters of Michaelis-Menten applied to the biomimetic sensor.

\begin{tabular}{|c|c|c|c|c|}
\hline Method calculated & $K_{\mathrm{M}}^{\mathrm{app}}$ & $k_{\text {cat }}$ & $k_{s}$ & $k_{e}^{\prime}$ \\
\hline LB plot analysis & 4.08 & 0.0123 & 3.02 & 1.04 \\
\hline EH plot analysis & 3.81 & 0.0121 & 3.17 & 1.09 \\
\hline HW plot analysis & 3.45 & 0.0118 & 3.42 & 1.18 \\
\hline Nonlinear curve fitting analysis & 3.42 & 0.0114 & 3.33 & 1.15 \\
\hline
\end{tabular}

LB = Lineweaver-Burke; EH = Eadie-Hofstee; HW = Hanes-Woolf; $K_{M}=\mu \mathrm{mol} \mathrm{L}^{-1} ; k_{\mathrm{cat}}=\mathrm{s}^{-1} ; k_{\mathrm{s}}\left(10^{3}\right)=\left(\mathrm{mol} \mathrm{L}^{-1} \mathrm{~s}^{-1} ; k_{e}^{\prime}\left(10^{-5}\right)=\mathrm{cm} \mathrm{s}^{-1}\right.$.

elementary chemical steps preceding the rate-determining step. On the basis of these results, the kinetic of nitrite oxidation on $\left.\left[\mathrm{Mn}_{2}{ }^{\mathrm{IV}} \mathrm{O}_{2} \text { (phen }\right)_{2}\left(\mathrm{H}_{2} \mathrm{O}\right)_{2}\right]^{4+} /$ Nafion ${ }^{\circledR} / \mathrm{GC}$ sensor can be described as:

$i_{K}=\frac{n F A k_{\mathrm{obs}} \Gamma\left[\mathrm{NO}_{2}^{-}\right]^{0.5}}{K_{\mathrm{M}}^{\mathrm{app}}+\left[\mathrm{NO}_{2}^{-}\right]^{0.5}}$

In this way, an alternative mechanism can be represented as:

$$
\begin{aligned}
& \mathrm{Mn}^{\mathrm{IV}}(\mu-\mathrm{O})_{2} \mathrm{Mn}_{(\text {sup })}^{\mathrm{IV}}+\mathrm{NO}_{2(\mathrm{aq})}^{-} \\
& \stackrel{k_{1}}{\longrightarrow}\left[\left(\mathrm{Mn}^{\mathrm{IV}}(\mu-\mathrm{O})_{2} \mathrm{Mn}^{\mathrm{IV}}\right)-\left(\mathrm{NO}_{2}\right)\right]_{(\text {sup })} \\
& {\left[\left(\mathrm{Mn}^{\mathrm{IV}}(\mu-\mathrm{O})_{2} \mathrm{Mn}^{\mathrm{IV}}\right)-\left(\mathrm{NO}_{2}\right)\right]_{(\text {sup })}+\mathrm{H}_{2} \mathrm{O}} \\
& \stackrel{k_{\text {cat }}}{\longrightarrow} \mathrm{Mn}^{\mathrm{III}}(\mu-\mathrm{O})(\mu-\mathrm{OH}) \mathrm{Mn}_{(\text {sup })}^{\mathrm{III}}+\mathrm{NO}_{3(\mathrm{aq})}^{-}+\mathrm{H}+
\end{aligned}
$$

where $\left[\left(\mathrm{Mn}^{\mathrm{IV}}(\mu-\mathrm{O})_{2} \mathrm{Mn}^{\mathrm{IV}}\right)-\left(\mathrm{NO}_{2}\right)\right]_{(\text {sup })}$ refers to the formation of a adduct between the metallic centers of the complex and the nitrite molecule.

\section{Conclusion}

This work described a biomimetic sensor for nitrite ions based on oxo-manganese complex immobilized on Nafion ${ }^{\circledR}$ ionexchange polymeric film coated glassy carbon electrode. The $\left.\left[\mathrm{Mn}_{2}{ }^{\mathrm{IV}} \mathrm{O}_{2} \text { (phen }\right)_{2}\left(\mathrm{H}_{2} \mathrm{O}\right)_{2}\right]^{4+} /$ Nafion $^{\circledR} / \mathrm{GC}$ exhibited electrocatalytic activity in the nitrite oxidation and biomimetic properties, allowing the study of the kinetic parameters of Michaelis-Menten in different methods. Furthermore, the biomimetic sensor showed low detection, high sensibility, affinity and catalytic production in fast times for nitrite ions.

\section{Acknowledgments}

The authors are thankful to São Paulo Research FoundationFAPESP (2005/01296-4) by research support. The scholarship granted by FAPESP (2013/10469-6) to W.B.S. Machini is gratefully acknowledged. The authors thank SJT.

\section{Appendix A. Supplementary data}

Supplementary data associated with this article can be found, in the online version, at http://dx.doi.org/10.1016/j.snb.2015.01.021.

\section{References}

[1] W.K. Jensen, C. Devine, M. Dikeman, Encyclopedia of Meat Sciences, Elsevier, Oxford, England, 2004.

[2] W.G. Stillwell, J. Glogowski, H.X. Xu, J.S. Wishnok, D. Zavala, G. Montes, P. Correa, S.R. Tannenbaum, Urinary-excretion of nitrate, $N$-nitrosoproline, 3 methyladenine, and 7-methylguanine in a Colombian population at high-risk for stomach-cancer, Cancer Res. 51 (1991) 190-194.

[3] N.S. Bryan, D.D. Alexander, J.R. Coughlin, A.L. Milkowski, P. Boffetta, Ingested nitrate and nitrite and stomach cancer risk: an updated review, Food Chem. Toxicol. 50 (2012) 3646-3665.

[4] N.P. Sen, P.A. Baddoo, Trends in the levels of residual nitrite in Canadian cured meat products over the past 25 years, J. Agric. Food Chem. 45 (1997) 4714-4718.
[5] K. Fukushi, T. Miyado, N. Ishio, H. Nishio, K. Saito, S. Takeda, S. Wakida, Determination of nitrite and nitrate in a proposed certified reference material for nutrients in seawater by capillary zone electrophoresis with artificial seawater as the background electrolyte using transient isotachophoresis, Electrophoresis 23 (2002) 1928-1934.

[6] T. Miyado, Y. Tanaka, H. Nagai, S. Takeda, K. Saito, K. Fukushi, Y. Yoshida, S Wakida, E. Niki, Simultaneous determination of nitrate and nitrite in biological fluids by capillary electrophoresis and preliminary study on their determination by microchip capillary electrophoresis, J. Chromatogr. A 1051 (2004) $185-191$

[7] E. Nagababu, J.M. Rifkind, Measurement of plasma nitrite by chemiluminescence without interference of $S$-, $N$-nitroso and nitrated species, Free Radic. Biol. Med. 42 (2007) 1146-1154.

[8] L. Wu, Z.M. Song, Y.A. Chen, H.Y. Zhu, Z.H. Li, Y. Gao, J. Yang, Y.D. Hung, Ion chromatographic determination of nitrite and nitrate in tobacco leaf, Asian J. Chem. 25 (2013) 9520-9522.

[9] N. Adarsh, M. Shanmugasundaram, D. Ramaiah, Efficient reaction based colorimetric probe for sensitive detection, quantification, and on-site analysis of nitrite ions in natural water resources, Anal. Chem. 85 (2013) 10008-10012.

[10] V. David, R.V. Perez, M. Matache, M.C. Icardo, J.M. Calatayud, Fluorimetric method for nitrite determination with proflavine, Rev. Roum. Chim. 48 (2003) 287-295.

[11] S. Kage, K. Kudo, N. Ikeda, Simultaneous determination of nitrate and nitrite in human plasma by gas chromatography-mass spectrometry, J. Anal. Toxicol. 26 (2002) 320-324

[12] U.T. Yilmaz, G. Somer, Determination of trace nitrite by direct and indirect methods using differential pulse polarography and application, J. Electroanal. Chem. 624 (2008) 59-63.

[13] W.X. Ma, J. Ji, O. Sha, Y.H. Liu, Simple and sensitive UV-spectrophotometric determination for trace amounts of nitrite with safranine T, Asian J. Chem. 25 (2013) 6277-6279.

[14] N. Pourreza, M.R. Fat'hi, A. Hatami, Indirect cloud point extraction and spectrophotometric determination of nitrite in water and meat products, Microchem. J. 104 (2012) 22-25.

[15] K. Veena, B. Narayana, Spectrophotometric determination of nitrite using new coupling agents, Indian J. Chem. Technol. 16 (2009) 89-92.

[16] I.A. Pettas, S.I. Lafis, M.I. Karayannis, Reaction rate method for determination of nitrite by applying a stopped-flow technique, Anal. Chim. Acta 376 (1998) 331-337.

[17] J. Lichtig, M. Olimpia, O. Rezende, Determination of nitrite ions in well water by biamperometric standard addition, Electroanalysis 5 (1993) 251-255.

[18] S.S.M. Hassan, S.A.M. Marzouk, H.E.M. Sayour, Selective potentiometric determination of nitrite ion using a novel (4-sulphophenylazo-)1-naphthylamine membrane sensor, Talanta 59 (2003) 1237-1244.

[19] G.H. Lu, J. Hong, S. Dandan, Determination of trace nitrite by anodic stripping voltammetry, Food Chem. 59 (1997) 583-587.

[20] M.G. Almeida, A. Serra, C.M. Silveira, J.J.G. Moura, Nitrite biosensing via selective enzymes-a long but promising route, Sensors-Basel 10 (2010) 11530-11555.

[21] H.S. Yin, Y.L. Zhou, T. Liu, L. Cui, S.Y. Ai, Y.Y. Qiu, L.S. Zhu, Amperometric nitrite biosensor based on a gold electrode modified with cytochrome $c$ on Nafion and Cu-Mg-Al layered double hydroxides, Microchim. Acta 171 (2010) 385-392.

[22] U.P. Azad, V. Ganesan, Efficient sensing of nitrite by Fe(bpy)(3)(2+) immobilized Nafion modified electrodes, Chem. Commun. 46 (2010) 6156-6158.

[23] Y.J. Li, C.Y. Chiu, Y. Huang, Biomimetic synthesis of inorganic materials and their applications, Pure Appl. Chem. 83 (2011) 111-125.

[24] R. Breslow, Centenary lecture-biomimetic chemistry, Chem. Soc. Rev. 1 (1972) $553-580$.

[25] C.S. Martin, M.F.S. Teixeira, Electrochemical properties of oxo-manganese complex biomimicking enzyme active sites and its electrocatalytic application for dopamine determination, Electrocatalysis-US 4 (2013) 92-100.

[26] T. Tzedakis, Electrochemical study of binuclear manganese complexes as catalysts in Kraft pulp bleaching, Electrochim. Acta 46 (2000) 99-109.

[27] C.S. Martin, M.F.S. Teixeira, A novel Mn-containing conducting metallopolymer obtained by electropolymerization in aqueous solution of a tetranuclear oxobridged manganese complex, Dalton Trans. 40 (2011) 7133-7136.

[28] A.I. Vogel, J. Mendham, Vogel's Textbook of Quantitative Chemical Analysis, sixth ed., Prentice Hall, Harlow, 2000.

[29] K.R. Reddy, M.V. Rajasekharan, N. Arulsamy, D.J. Hodgson, Synthesis and structural investigations of $\left[\mathrm{Mn}_{3} \mathrm{O}_{4}\right.$ (phen) $\left.(4)\left(\mathrm{H}_{2} \mathrm{O}\right)(2)\right]\left(\mathrm{NO}_{3}\right)(4)$ center dot 2 center dot 5H(2)O: a water-bound complex obtained by cerium(IV) oxidation, Inorg. Chem. 35 (1996) 2283-2286.

[30] C.A. Caro, F. Bedioui, J.H. Zagal, Electrocatalytic oxidation of nitrite on a vitreous carbon electrode modified with cobalt phthalocyanine, Electrochim. Acta 47 (2002) 1489-1494. 
[31] M.H. Pournaghi-Azar, H. Dastangoo, Electrocatalytic oxidation of nitrite at an aluminum electrode modified by a chemically deposited palladium pentacyanonitrosylferrate film, J. Electroanal. Chem. 567 (2004) 211-218.

[32] W.B.S. Machini, M.F.S. Teixeira, Electrochemical properties of the oxomanganese-phenanthroline complex immobilized on ion-exchange polymeric film and its application as biomimetic sensor for sulfite ions, Electroanalysis 26 (2014) 2182-2190.

[33] P. Bertoncello, P. Ugo, Preparation and voltammetric characterization of electrodes coated with Langmuir-Schaefer ultrathin films of Nafion ${ }^{\circledR}$, J. Braz. Chem. Soc. 14 (2003) 517-522.

[34] M.F.S. Teixeira, F.H. Cincotto, P.A. Raymundo-Pereira, Electrochemical investigation of the dimeric oxo-bridged ruthenium complex in aqueous solution and its incorporation within a cation-exchange polymeric film on the electrode surface for electrocatalytic activity of hydrogen peroxide oxidation, Electrochim. Acta 56 (2011) 6804-6811.

[35] A.J. Bard, L.R. Faulkner, Electrochemical Methods: Fundamentals and Applications, second ed., Wiley, New York, NY, 2001.

[36] B. Steiger, C. Padeste, A. Grubelnik, L. Tiefenauer, Charge transport effects in ferrocene-streptavidin multilayers immobilized on electrode surfaces, Electrochim. Acta 48 (2003) 761-769.

[37] P.J. Kulesza, Solid-state electrochemistry of iron hexacyanoferrate (Prussian Blue type) powders-evidence for redox transitions in mixed-valence ionically conducting microstructures, J. Electroanal. Chem. 289 (1990) 103-116.

[38] L. Authier, B. Schollhorn, J. Moiroux, B. Limoges, Ion-exchange voltammetry at a surfactant-doped electrode: model of mass transfer kinetics to an anionic surface-charged electrode and its application for the sensitive determination of alkaline phosphatase, J. Electroanal. Chem. 488 (2000) 48-58.

[39] Rh. Wopschal, I. Shain, Adsorption effects in stationary electrode polarography with a chemical reaction following charge transfer, Anal. Chem. 39 (1967) 1535-1542.

[40] M. Tagliazucchi, E.J. Calvo, I. Szleifer, Molecular theory of chemically modified electrodes by redox polyelectrolytes under equilibrium conditions: comparison with experiment, J. Phys. Chem. C 112 (2008) 458-471.

[41] S.J. Dong, Z. Jin, Electrochemistry of indium hexacyanoferrate film modified electrodes, Electrochim. Acta 34 (1989) 963-968.

[42] A.Y. Chamsi, A.G. Fogg, Oxidative flow-injection amperometric determination of nitrite at an electrochemically pre-treated glassy-carbon electrode, Analyst 113 (1988) 1723-1727.

[43] B.R. Kozub, N.V. Rees, R.G. Compton, Electrochemical determination of nitrite at a bare glassy carbon electrode: why chemically modify electrodes? Sens. Actuators B: Chem. 143 (2010) 539-546.

[44] T.S. Liu, T.F. Kang, L.P. Lu, Y. Zhang, S.Y. Cheng, Au-Fe(III) nanoparticle modified glassy carbon electrode for electrochemical nitrite sensor, J. Electroanal. Chem. 632 (2009) 197-200.

[45] R. Guidelli, Voltammetric behavior of nitrite ion on platinum in neutral and weakly acidic media, Anal. Chem. 44 (1972) 745-755

[46] T.R.L. Dadamos, M.F.S. Teixeira, Electrochemical sensor for sulfite determination based on a nanostructured copper-salen film modified electrode, Electrochim. Acta 54 (2009) 4552-4558.

[47] M.E.G. Lyons, T. Bannon, G. Hinds, S. Rebouillat, Reaction/diffusion with Michaelis-Menten kinetics in electroactive polymer films-Part 2. The transient amperometric response, Analyst 123 (1998) 1947-1959.

[48] M.E.G. Lyons, C.A. Fitzgerald, M.R. Smyth, Glucose-oxidation at ruthenium dioxide-based electrodes, Analyst 119 (1994) 855-861.

[49] I. Prigogine, S.A. Rice, Polymeric Systems, Wiley, New York, Chichester, 1996.

[50] G.A. Petsko, Structure and mechanism in protein science: a guide to enzyme catalysis and protein folding, Nature 401 (1999) 115-116.

[51] K.F. Faull, W. Wallace, D.J. Nicholas, Nitrite oxidase and nitrate reductase in Nitrobacter agilis, Biochem. J. 113 (1969) 449-455.

[52] D.L. Nelson, M.M. Cox, A.L. Lehninger, Lehninger Principles of Biochemistry, fourth ed., Freeman, New York, NY, 2005.

[53] M.J. Klink, E.I. Iwuoha, E.E. Ebenso, The electro-catalytic and redox-mediator effects of nanostructured PDMA-PSA modified-electrodes as phenol derivative sensors, Int. J. Electrochem. Sci. 6 (2011) 2429-2442.

[54] B. Palys, A. Bokun, J. Rogalski, Poly-o-phenylenediamine as redox mediator for laccase, Electrochim. Acta 52 (2007) 7075-7082.

[55] F. Aulenta, A. Canosa, L. De Roma, P. Reale, S. Panero, S. Rossetti, M. Majone Influence of mediator immobilization on the electrochemically assisted microbial dechlorination of trichloroethene (TCE) and cis-dichloroethene (cis-DCE), J. Chem. Technol. Biotechnol. 84 (2009) 864-870.

[56] R.G. Compton, Electrode Kinetics: Reactions, Elsevier, Amsterdam, New York, NY, 1987

[57] X. Huang, Y.X. Li, Y.L. Chen, L. Wang, Electrochemical determination of nitrite and iodate by use of gold nanoparticles/poly(3-methylthiophene) composites coated glassy carbon electrode, Sens. Actuators B: Chem. 134 (2008) 780-786.
[58] V. Biagiotti, F. Valentini, E. Tamburri, M.L. Terranova, D. Moscone, G. Palleschi Synthesis and characterization of polymeric films and nanotubule nets used to assemble selective sensors for nitrite detection in drinking water, Sens. Actuators B: Chem. 122 (2007) 236-242.

[59] X.W. Chen, F. Wang, Z.L. Chen, An electropolymerized Nile Blue sensing filmbased nitrite sensor and application in food analysis, Anal. Chim. Acta 623 (2008) 213-220.

[60] K. Zhao, H.Y. Song, S.Q. Zhuang, L.M. Dai, P.G. He, Y.Z. Fang, Determination of nitrite with the electrocatalytic property to the oxidation of nitrite on thionine modified aligned carbon nanotubes, Electrochem. Commun. 9 (2007) 65-70.

[61] V. Mani, A.P. Periasamy, S.M. Chen, Highly selective amperometric nitrite sensor based on chemically reduced graphene oxide modified electrode, Electrochem. Commun. 17 (2012) 75-78.

[62] N.N.Zhu, Q. Xu, S.N. Li, H. Gao, Electrochemical determination of nitrite based on poly(amidoamine) dendrimer-modified carbon nanotubes for nitrite oxidation, Electrochem. Commun. 11 (2009) 2308-2311.

[63] D.Y. Zheng, C.G. Hu, Y.F. Peng, S.S. Hu, A carbon nanotube/polyvanillin composite film as an electrocatalyst for the electrochemical oxidation of nitrite and its application as a nitrite sensor, Electrochim. Acta 54 (2009) 4910-4915.

[64] M.A. Kamyabi, F. Aghajanloo, Electrocatalytic oxidation and determination of nitrite on carbon paste electrode modified with oxovanadium(IV)-4-methyl salophen, J. Electroanal. Chem. 614 (2008) 157-165.

[65] B. Unnikrishnan, P.L. Ru, S.M. Chen, V. Mani, Nitrite determination at electrochemically synthesized polydiphenylamine-Pt composite modified glassy carbon electrode, Sens. Actuators B: Chem. 177 (2013) 887-892.

[66] L.Y. Jiang, R.X. Wang, X.M. Li, L.P. Jiang, G.H. Lu, Electrochemical oxidation behavior of nitrite on a chitosan-carboxylated multiwall carbon nanotube modified electrode, Electrochem. Commun. 7 (2005) 597-601.

[67] B.Q. Yuan, C.Y. Xu, L. Liu, Y.F. Shi, S.J. Li, R.C.Zhang, D.J.Zhang, Polyethyleniminebridged graphene oxide-gold film on glassy carbon electrode and its electrocatalytic activity toward nitrite and hydrogen peroxide, Sens. Actuators B: Chem. 198 (2014) 55-61.

[68] G. Yildiz, N. Oztekin, A. Orbay, F. Senkal, Voltammetric determination of nitrite in meat products using polyvinylimidazole modified carbon paste electrode, Food Chem. 152 (2014) 245-250.

[69] U.P. Azad, S. Turllapati, P.K. Rastogi, V. Ganesan, Tris(1,10-phenanthroline) iron(II)-bentonite film as efficient electrochemical sensing platform for nitrite determination, Electrochim. Acta 127 (2014) 193-199.

[70] S. Radhakrishnan, K. Krishnamoorthy, C. Sekar, J. Wilson, S.J. Kim, A highly sensitive electrochemical sensor for nitrite detection based on $\mathrm{Fe}_{2} \mathrm{O}_{3}$ nanoparticles decorated reduced graphene oxide nanosheets, Appl. Catal. B-Environ. 148 (2014) 22-28

[71] Y. Li, H. Wang, X. Liu, L. Guo, X. Ji, L. Wang, D. Tian, X. Yang, Nonenzymatic nitrite sensor based on a titanium dioxide nanoparticles/ionic liquid composite electrode, J. Electroanal. Chem. 719 (2014) 6.

[72] P. Astorga, C. Canales, M. Antilen, G. Ramirez, Glassy carbon electrode modified with nickel(II) tetrasulfophtalocyanine films and its behavior as amperometric sensor for nitrite, Int. J. Electrochem. Sci. 9 (2014) 109-119.

[73] L.H. Chen, J.B. Zang, Y.H. Wang, L.Y. Bian, Electrochemical oxidation of nitrite on nanodiamond powder electrode, Electrochim. Acta 53 (2008) 3442-3445.

[74] F.X. Hu, S.H. Chen, C.Y. Wang, R. Yuan, D.H. Yuan, C. Wang, Study on the application of reduced graphene oxide and multiwall carbon nanotubes hybrid materials for simultaneous determination of catechol, hydroquinone, $p$-cresol and nitrite, Anal. Chim. Acta 724 (2012) 40-46.

\section{Biographies}

Wesley Bruno Silva Machini received the graduate degree in Chemistry from São Paulo State University (2012). At present, he is a postgraduate student (Master Science) in Analytical Chemistry at the Department of Physics, Chemistry and Biology of the São Paulo State University and his research interests include integrated electrochemical and biomimetic sensors.

Marcos Fernando Souza Teixeira obtained his $\mathrm{PhD}$ degree (Analytical Chemistry) in 2000 at the Federal University of São Carlos. Currently, he is an associate professor at the Department of Physics, Chemistry and Biology of the São Paulo State University (UNESP)-Campus of Presidente Prudente. His research interests are in the development of chemical sensing concepts, electrochemical sensors based on polymeric sensing phases and environmental electroanalytical. 